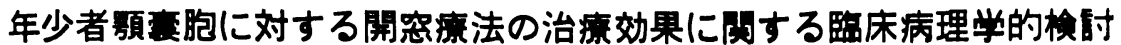

\author{
千葉 清・工藤 啓 吾・小川邦明・小口順 正 \\ 班目幸恵・藤岡幸雄・佐藤良三*・黒甽雅行* \\ 嶋中豊彦*・鈴木漹美*
}

\section{Clinicopathological investigation of the cysts of the jaw of young patients with the special reference to the effects of marsupialization}

\author{
Kiyoshi Chiba - Keigo Kudo - Kuniaki Ogawa - Yukimasa Oguch \\ Yukie Madarame - Yukio Fujroka - Ryozo Sato* - Masayuki Kuroda* \\ Toyohiko Shimanaka* . Atsumi Suzuki*
}

緒

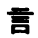

顥衰胞に対する治療法は，摘出手術療法を基本とし， 古くから Partsch のI法およびII 法が用いられ，最近 は抗生物質の発達および麻酔法の進歩によってこれらの 方法や変法が容易に実施されるよらになった。しかしな から，いずれの方法においても，年龄や践胞の大きさお よび位直，隣接組織の状態あるいは血管および神経の走 行，在歯などとの関連性を常に考虑する必要があり， さらに年少者では䝷発育への影響, 外科的侵襲, 顔貌の 変形など肉体的ならびに精神的影变を可及的に少なくす るよう配虑すべきであると考えられる。

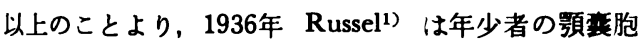
に対しては，開空療法がきわめて有効であることを提唱 し，その後本邦においても1962年小幡ら ${ }^{2,3)}$ がはじめて 本法の経験例を報告し，じらい諸家 ${ }^{4 \sim 9)}$ による数多くの 治験例が報告されるよらになった。

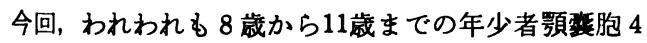
症例に対して開空療法を試み，その経時的変化を臨休 的, X線的に観察し，かつ生検による病理組織所見をる

岩手医科大学齿学部口腔外科学第 1 講座（主任：

\section{藤岡幸雄教授）}

岩手医科大学齿学部口腔病理学犝座（主任：鉿木 鐭美教投)

First Department of Oral Surgery, School of Dentistry, Iwate Medical College (Chief: Prof. Yukio Fujioka)

* Department of Oral Pathology, School of Dentistry, Iwate Medical College (Chief: Prof. Atsumi Suzuki)

受付日 : 昭和 52 年 8 月 15 日
あわせ，その治療効果の意義を考察したところ興味ある 知見を得たのでここに報告する.

\section{症例}

4 症例の概要は表 1 のごとくであるが，以下おのおの の症例について詳細に述べる.

症例 $1 ：$, 8 歳 女性.

初 診: 昭和 45 年 4 月 .

現病歴：約 1 か月前より右下頓部の腫脹に気ついたが 疼痛がないため放㯰していた，最近，腫脹が増大するた め某歯科を受診し，当科を紹介されて来院した。

主 訴: 右下頓部の隀脹.

局所所見：顔貌は左右非対称性で，右下頓部に䳝卵大 の腫脹が認められ, 境界は比較的明瞭で中等度の圧痛か; 認められた. 口腔内は $\overline{6 \mathrm{E} \mathrm{43}}$ 畨肉から齿肉頓移行部 にかけて沜卵大に腫脹し, 表面粘膜はやや発赤して, 軽 度の圧痛があり, 境界は比較的明暸で一部に羊皮紙様感 が触知された。

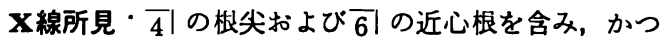
下顠骨下縁に接して $32 \times 22 \mathrm{~mm}$ の単胞性, 楕円形のX線 透過像が認められ，その透過像内には可|に接して兯が 埋伏し，また $\overline{\mathrm{E}} \mid$ の歯根は約4/5が吸収されていた（写志 1).

処置および経過 : 初診時に馬を抜歯し，同部の歯槽 頂から雪肉頓移行部にかけて約 $2 \mathrm{~cm}^{2}$ の生検をかねた開 䆖を施行し (写真 2), 経時的に肉眼的, $\mathbf{X}$ 線的経過観 察を行った. 開空後 3 か月で烡胞腔は不明瞭となり, かつ埋伏していた 5 | は開空部に崡冠が萌出し, 菙胞腔 周囲に骨増生像と思われるX線不透過像が明らかに認め られるよらになった。5か月後には变胞腔がかなり縮小 
表 1

\begin{tabular}{|c|c|c|c|c|c|c|c|}
\hline 证: 例 & 部们。 & 大き & 断 & 経 & 埋 & 蔽 & 涌 \\
\hline $\begin{array}{c}1 . \\
8 \text { 韵 } \\
9\end{array}$ & $6 \longdiv { \mathrm { E } \mathrm { 41 } }$ & $32 \times 22 \mathrm{~mm}$ & 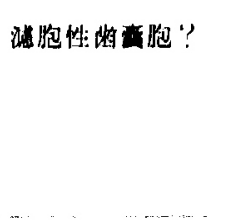 & 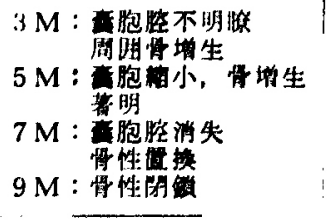 & 拔 & 米 & 7 年䄳通 \\
\hline $\begin{array}{c}9 . \\
9 \text { 械 } \\
\text { ô }\end{array}$ & $\left(\begin{array}{llll}E & 4\end{array}\right.$ & $36 \times 23 \mathrm{~mm}$ & 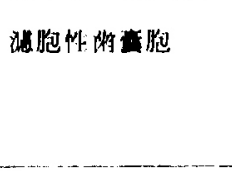 & 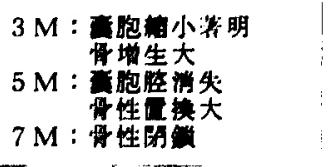 & 拔 & 每 & 2 年政温 \\
\hline 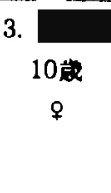 & 456 & $36 \times 25 \mathrm{~mm}$ & 洗胞性的责胞 & 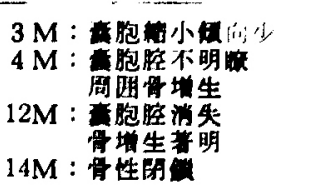 & $\therefore$ & L & 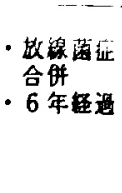 \\
\hline$\underset{\substack{11 \\
\text { 藏 }}}{\text {. }}$ & $\overline{\mid 6} \sim$ 下䫑枝 $\mid$ & $55 \times 35 \mathrm{~mm}$ & 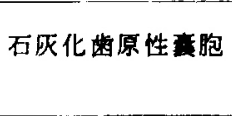 & 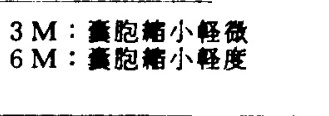 & 筒狍持 & $\begin{array}{l}\text { 出 } \\
\text { 抜曾 }\end{array}$ & 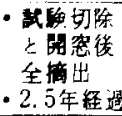 \\
\hline
\end{tabular}

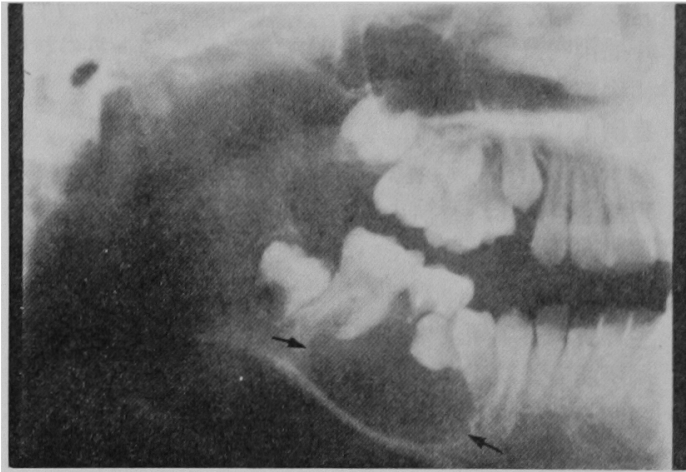

写真 1 症例 1：初訩時のpanorama X線写真

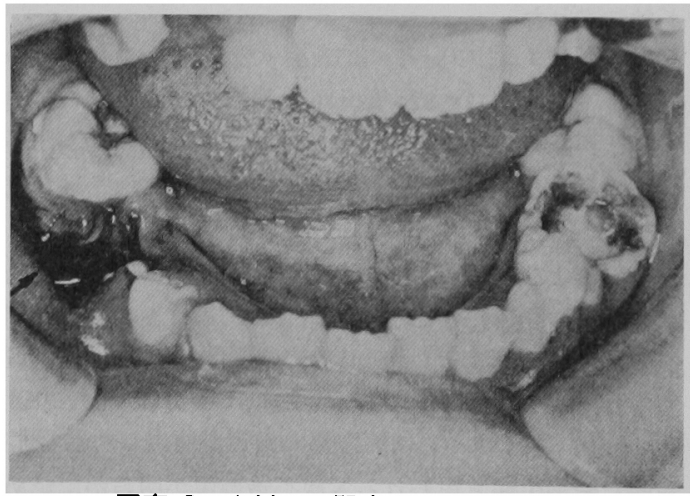

写真 2 症例 $1 ：$ 開密時の口腔内所見

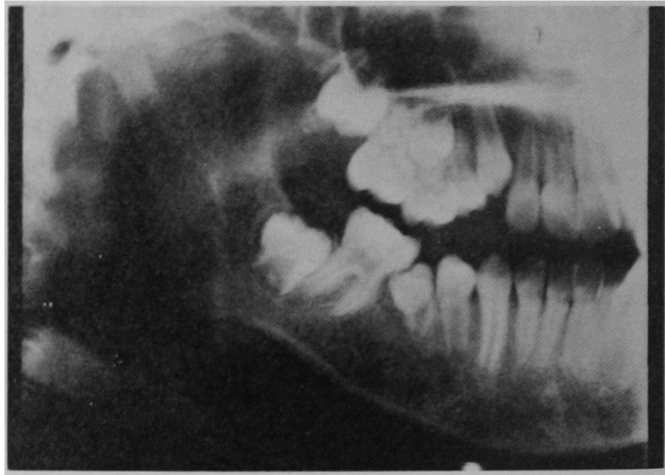

写而 3 症例 1 ：開密媵 9 か月目の panorama X線写真

し，骨の増生像が著明となり，7か月後には黄胞腔は完 全に消失して，骨によって圈換された像を呈していた， さらに9か月後には鹪胞腔は完全に骨組織によって置き かえられ，正常の影骨の形態に復していた（写真了）。開 空部に萌出した $\overline{5} \mid$ は可|および

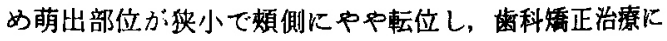
協力しなかったためやむなく開空後 9 か月目に技齿し た，拔去霜はやや短根歯て，かつ肥大根を呈していた。 開空後 7 年以上释過観察を行っているが良好である。

\section{病理組織所見}

等胞壁内面は，原性上皮由来と思われる重㬝扁平上 皮によって被覆されている。この上皮は敦胸壁飞存在す る慢性炎症のために资性增殖を示している（写真4-A）。 


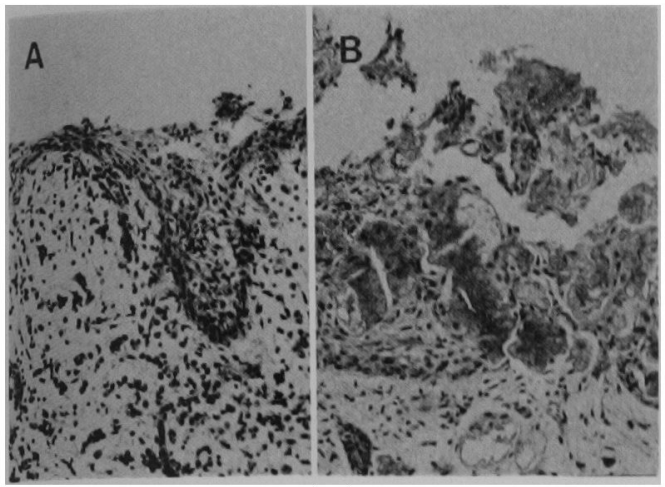

军辛 4

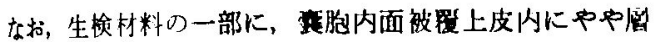
状の石灰化物を認めたか，この所見のみからでは石灰化 歯原性焦胞と確㟝することはできなかった（写声 4-B).

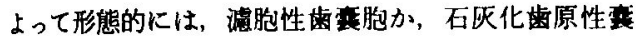

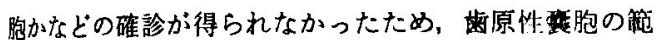

言烦るるのとして処理した。

症例 2： 9 歳 男性.

初診: 昭和 50 年 8 月

現病歴：約 3 か月前より右奤角部の尰脹に気づき， 3 日前某函科を受診し当科を紹介されて来院した。

主 訴: 右下煩部の腫脹。

局所所見：顔貌は左右非対称性で，右顎角部から右下

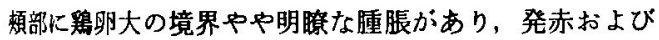
熱感はともにないが，軽度の圧痛が虫められた，口腔内 は $\overline{6 \mathrm{E} 4}$ 歯肉から粚肉頪移行部にかけてらずら卵大の 連脤が諗められ，表面粘膜は正常色を呈し正痛はないか， 弾性硬で $\overline{\mathrm{E}}$ 部菊肉に軽度の羊皮紙様感が触知された。

X楾所見： $\overline{6}$ の遠心根， 3 の雪胚および から下顥骨下縁にかけて境界明膫な単胞性の32×23 mm の棈円形を呈するX線透過像が認められ，その透過像内 に司は娌伏し， $\mathbf{E}$ の菌根は4/5が吸収されていた（写 I5).

処置および䅅過：症例 1 と同様に $\overline{\mathrm{E}}$ を拔菌し，生検 をかねた約 $2 \mathrm{~cm}^{2}$ の開空を行った。 1 か片には韯胞腔 の境界が不明瞭となり，周囲に骨増生が著明にみられ， 3か月後には丧胞腔はほぼ縮小し，幼若新生骨と思われ るX線不透過像の增大が著しくなった。 また埋伏した 万人は開空部に萌出してきたか，煩側にやや転位して萌 出したため, 症例 1 同様の理由で抜去した。 5 か月後に は童胞腔はほほ消失し，肉眼的に肉芽組織で満たされ， X線的にも骨によって置換されていると判定される所見 を呈するよ5になった，その後 2 年以上経過観察してい るが良好である。

病理組端所見

開空時の生検所見では，趸胞壁内面が症例 1 にお゙ける

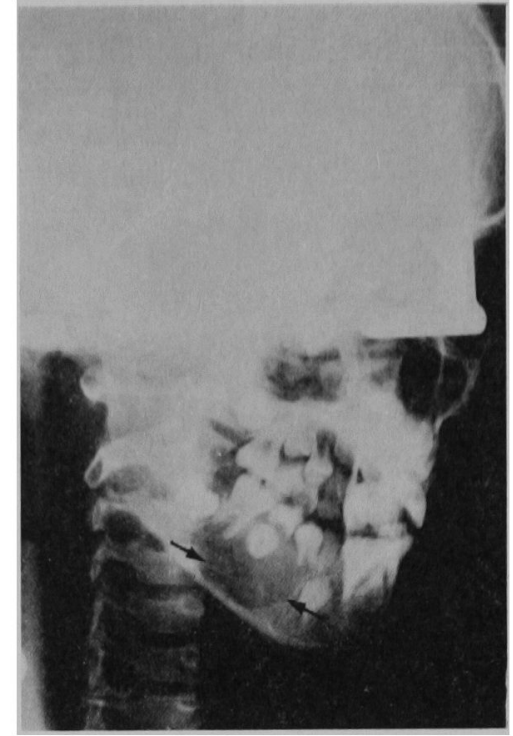

写真 5 症例 2 : 初診时の oblique cephalo X線写真
A

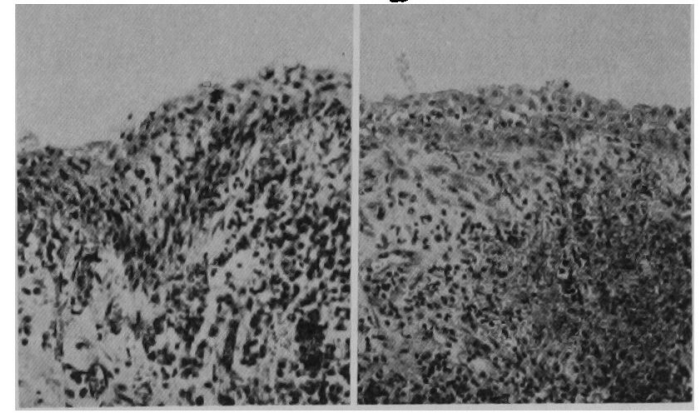

军直 6

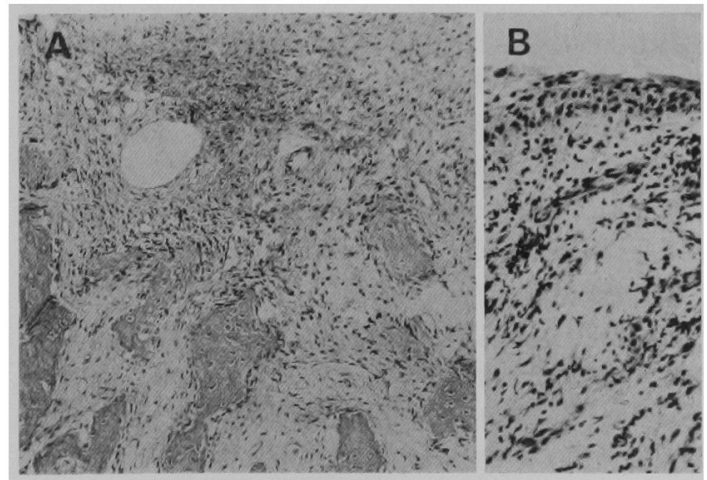

军直 7 


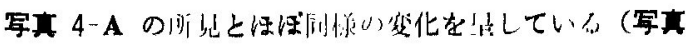

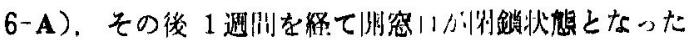

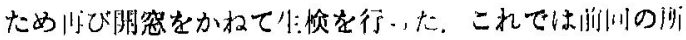

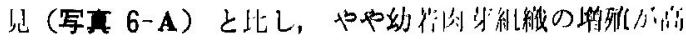

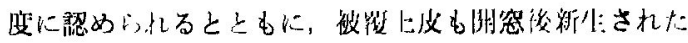

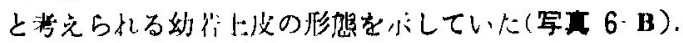

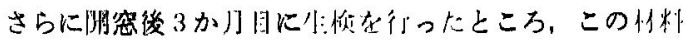

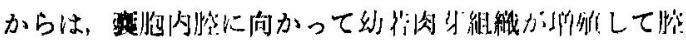

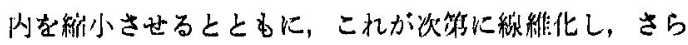

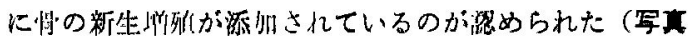

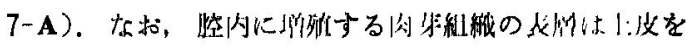

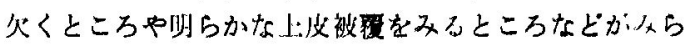
れた (军市 7-B).

症例 3

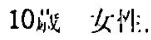

初讋: 㸛和46作 1 月

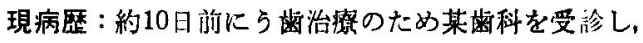

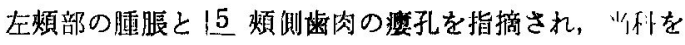
受診した。

主 訴：左頓部の腫脹。

局所所見：顔貌は左在非刘称性で左煩部に鳵卵大の境

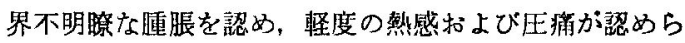

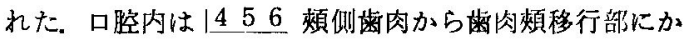
けて比較的境界明瞭な鳵卵大の腫脹が認められ，表面粘 膜は発赤し，軽度の压痛が認められた。硬度は学様硬で

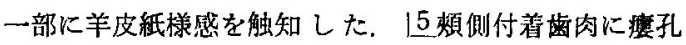

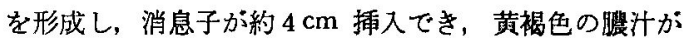
認められた。

X線所見：1456 の根尖括よび眼䆚下缘に及ぶ境界 比較的明瞭な単胞性を呈する $36 \times 25 \mathrm{~mm}$ のX線䢟過像が 認められた（写真 8 ).

処置および経過：15を拔齿し，試験切除をかねた開 空を施行した，炎症を合併していたため Josamycin $200 \mathrm{mg}$ を 1 日 4 回，3 日間投与し消炎を行ったところ，

7 日目には炎症症状が消退した。開空後 3 か月経過して b蕉胞腔の縮小傾向は軽度であったが，4か月後には栾 胞腔の境界がやや不明膫となり，骨新生像も軽度に認め られるようになった。12か月後には整胞腔はほぼ完全に 消失し骨の增殖が著明に羿められ，肉眼的にも消息子が $2 \mathrm{~mm}$ 程度しか插入できない状態となった，14か月後に は夜胞は完全に骨組織によって置さかえられ，ほぼ正常 の顎骨の形態に復し表面粘膜は軽度に症痕化した。 その 後 6 年以上経過観察しているが良好である。

\section{病理組織所見}

開空時の生検所見では幼若な肉芽巣の一部に明らかな 膿瘍が存在し，その中に放線菌塊が認められた（写直 9 一A). 開空後 7 日目の生検所見では宷原性上皮の被覆を もつ跴胞壁の形態を示し，若い次性肉芽組織の增生をみ ることができた（写真 $9-\mathbf{B}$ ).

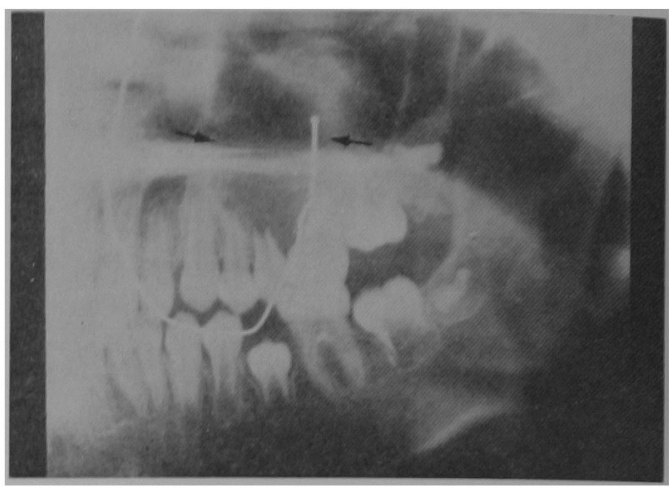

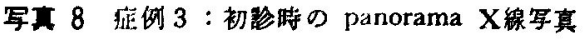

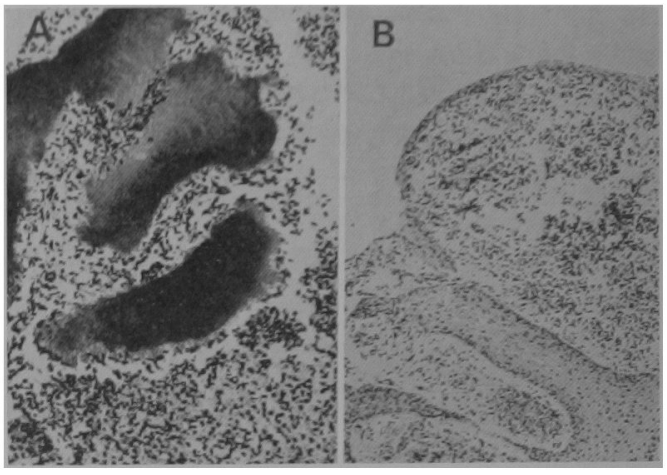

军再 9

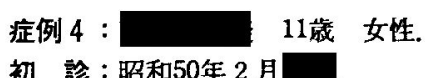

初診：昭和50年 2 月

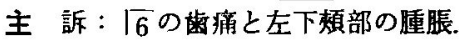

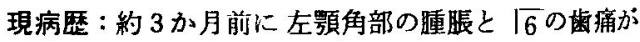
みられたため，某歯科を受䛦し本学小胃歯科を紹介され た．X線診查で異常を指摘され，さらに当科を紹介され 来院した.

局所所見：顔貌は左右非対称性で左䫑角部から下頼部 にかけて珢大，溷漫性の腫脹があり，発赤はないが， 弾性硬で軽度のE痛が認められた。只腔内所見は原頓

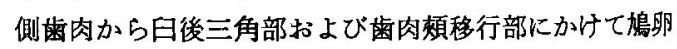

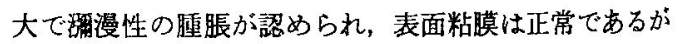
骨様硬で軽度の艮痛が認められた。

$\mathbf{X}$ 線所見： $\sqrt{6}$ 䞦心根を含んで,から買角部から下顎枝 部にわたる単胞性の境界明暸な $55 \times 35 \mathrm{~mm} の X$ 線透過像 が認められ，原遠心根の一部に吸收像がみられた。 の透過像内には根末完成な $\sqrt{7}$ が埋伏し，また原近心根 尖部にも境界やや明瞭なX線透過像が認められた（写真 10).

処置および経過： $\sqrt{6}$ を抜崡し，同部に生検をかねた 開空を $2 \times 1 \mathrm{~cm}^{2}$ の棈円形状に行った. 開空後 3 か月て 


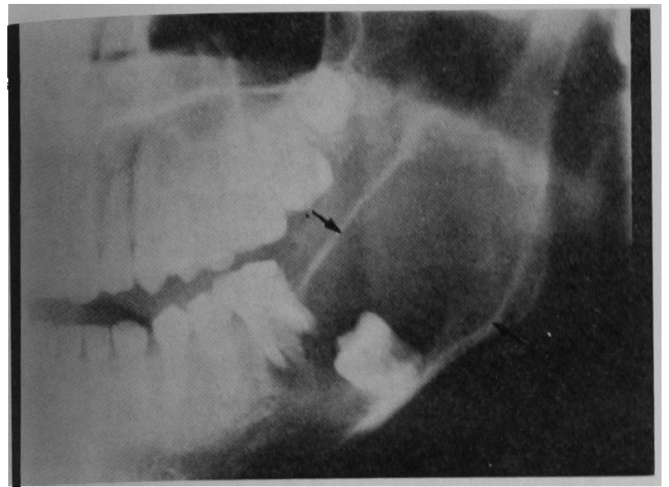

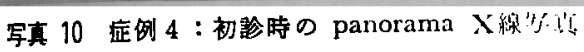

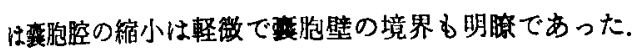
6か月後には，咅胞壁もやや不明瞭となってきたが粳小 頃向が軽度であったため，全身麻醉下にわずかに開空部

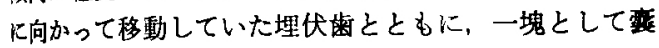
胞摘出術を行った. 手術創は開放創とし, 術後 1 か月目 では同部のX線透過像は漸次縮小し，5か月後には大部 分が骨によって置換され，6か月後にははぼ完全に骨の 愎增生がみられ治瘾した，その後 2 年以上释過钼察を 行っているが良好である。

\section{病理組啝所見}

開空時の生険所見では，戔胞壁内側がェナメル器類似 の歯原上皮によって被覆され，上皮内には多数の ghost cell，石灰化物などが琶められ，組織的には石灰化雪原 生滖胞であった（写真 11）。開空 6 か月後に得た摘出物 の全割醥本では，一部の衰胞壁内面は炎性增殖を示す重 層扁平上皮と化し，上皮下には肉芽組織が增殖し品胞壁 の縮小が認められる（写直 12-A）。しかし他の竞胞壁

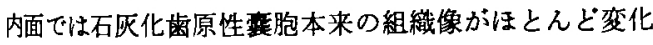
していないことが注目された（写真 12-B）。すなわち 壁組織の改造変化の少ない部位では变胞腔の縮小を期待 することはできないと思われた。

\section{考按}

開空㞠法は蕉胞壁の一部を切除し，口腔と交通させ， 胞内溶液の流出およびその内王の減少をはかることに よって，周囲骨組織の再生を促進させ荛胞膑の縮小をは かる方法であって Partsch第I法の変法と考克られる.

近年, 年少者顎重胞に対する本法は種なの観点よりさ わめてすぐれた治㞠法として注目されている，小幡 よれば開空療法は，1）外科的侵嶈がきわわて少なく，

2) 䫓骨の発育, 顔貌の変化に与える影響がほとんどな い.3）開空という簡単な外科的処置のあとは，経時的 に臨床像およびX線像による観察が行われるならば外来 竞㬌として，治癒あるいは適当な手術時期までの処置と

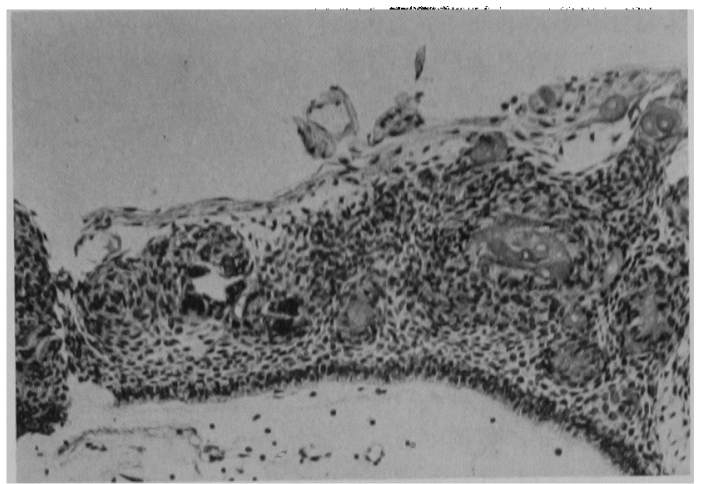

军素 11

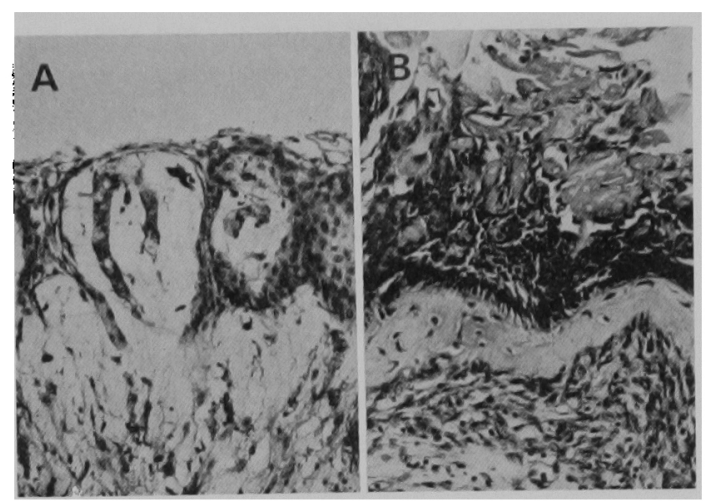

写啹 12

して十分に目的を達することができる，と述べている。 また Thoma ${ }^{10)}$ はその長所として，1）簡単である. 2) 特殊な技術を要しない，3）術後における創の治疹 が根治的外科切除例より早いと述へ，短所としては， 1) pocket を形成し，食物残㚗が貯りやすく不橴とな り，長期間洗浄を必要とする，2）再発の可能性があ る、3）完全治瘜でないことなどを指摘している。

われわれの経験した 4 例中 3 例はいずれも濾胞性歯趸 胞（らち筑いのあの1例を含む）であり，これらははほ 完全に骨の再生修復を認め，臨床的にあX線的にもきわ

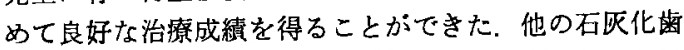
原性霍胞の 1 例は開空後 6 か月経過してd樎小㑯向が軽 度なため摘出した。しかし生検をかねた開空療法を行ら ことによって，正確な組織診断が得られ，かつ蒜胞を拡 大させることなく手術時期を延長させることができたこ とは注目される。

本療法は以上のよらに，留胞の性状によっては必ずし る臨床的に好結果を得るとは限らないため，その適応の 巽択には十分な注意が必要である，上野 ${ }^{11}$ は本潦法の適 応症として，1）年少者の葆胞性エナメル上皮腫，2） 感染衰胞，3）放射線治療を行った上顎洞癌，4）反覆 再発性歯肉膿瘍をあげている。エナィル上皮腫に対して 
本潠法がその適応であるとの見解については、ェナィル

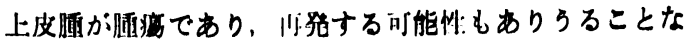

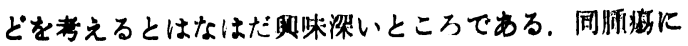

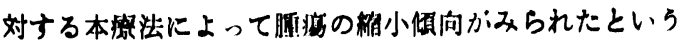

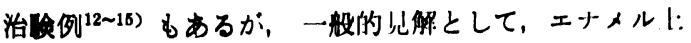
皮胍に対する本撩法の適応は根恰治祭に少だって行われ る予俌的あるいは前処䍀的意味をるったるのと考えられ ている.

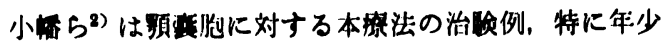
者例においてはそれらのはとんどが終的な外科的処湖 を必要とせ才゙，佂例に上っては用の归生，埋伏齿还の発 育が正常に行われたと述へてている，われわれの経段した

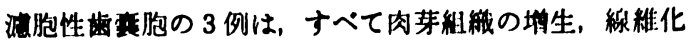

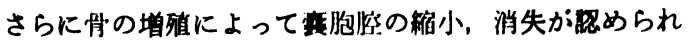
烡胞の種類によっては必ずしも予借的, 前処情的な治療 法にとどまるものではないことが立証された。 したがっ て過去の例と，今回の自耠例とをあわせて考察すると， 本療法は年少者の衰胞性疾思に対して，まず第一に試み てみるべき治療法であると考えられる。

基胞腔内埋伏歯について，われわれは埋伏歯が最終的 に頓側に転位した状態に萌出し，また齿科镉正治㫱に協 カしなかったため拔齿した。しかし煩側転位した原因 は, 開空部隣在齿の近遠心的移動に上って埋伏雪の萌出 に必要な空間が狭小となったためと考えると，本療法の 経過钼察中に内溶液の誘導装展をかねた保陌装置を作製 する必要性を痛感した。このよらな誘導装膡を用いた治 験例 ${ }^{7}$ 16) 散見されることから，今後はこの点について 検討を加え，埋伏歯の運命を追求していきたい．

さて，われわれの経験した症例のよらにX線的に䫓骨 内の透過像を示す病変は数多くみられるので, 生検をか ねた開空療法は確定診断を行ら上からも非常に有効な手 段と思われる.ささらに経過観察時にも生検を施行する と，衰胞壁の性状の変化も知ることができる．たとえば 症例 2 の開空 3 か月後の生検所見では衰胞壁か消失し, 炎性肉芽組織の增殖と幼若新生骨の形成がみられた。 た縮小順向の軽度であった症例 4 の摘出全割骠本の病理 組織所見では，一部縮小傾向のみられた部位には，壁組 織内面に肉芽組織の增殖とともに被覆上皮も重層扁平上 皮と化していたか，他の部位は石灰化歯原性亳胞本来の 形態があまり変化せずに残遺し，その部の縮小傾向は軽 微であった. 以上のような組織所見を基として本㞠法の 意義を考察すると, 開空療法によって起こる烡胞腔の縮 小は，震胞の内圧減少によって烡胞壁が本来の性状を失 い, 考胞腔内に肉芽組織の增殖, 線維化さらに骨組織の 増殖が起こり, 巷胞腔が縮小していくものであろらと考 えられた。

\section{結 \\ 解}

われわれは8放より11放までの4 例の年少者頑衰胞飞 対して阴空挜法を武みた練果，次のよ5な結論を得た。

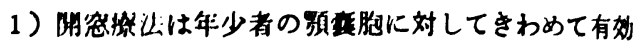
な治撩法であり，まず第一義的に浾みるべき方法である と考えられた。

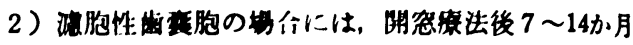

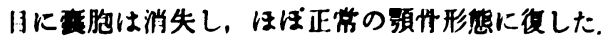

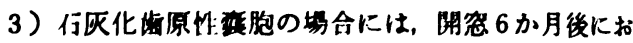

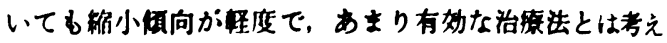
られなかった。

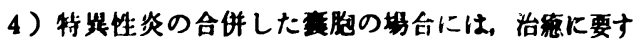

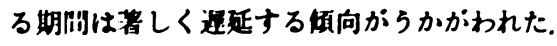

5）生饮をかかて閶空を実施することは，その診断の

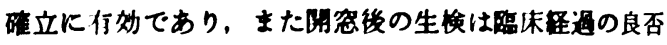
を判定するのに有奻であった

6）本法の実施にあたっては，閏空後経時的にX線的 ならびに踽床的に経過钼察を行らことがきわめて重要で あった。

7）開空によって套胞が消失するのは，内压の娍少に より赛胞壁の性状が失われて肉芽組織の增殖, 線維化， さらに骨組織の增殖による改变化が起こるためである ことが組織学的に磪詔できた。

$$
\text { 文致 }
$$

1) Russel, A.Y.: Conservative Management of Bone Cysts in Children and Adult. J Amer Dent Assoc 23: 17191936.

2）小幸男，他：额衰咆の保存的法飞ついて (抄). 日只外誌 8: 2061962.

3）小累：頻重胞の開愙法について。病誌 33: 4271966.

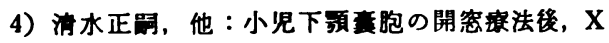

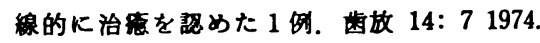

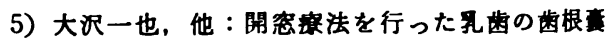
胞の 1何. 口科誌 20:823 1971.

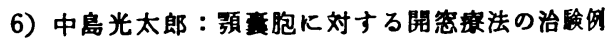
(抄)。科誌 22: 4971973.

7）佐藤正一郎，他：誘尊装置をるらいた開空帛の 治全例（抄）。旦外誌 20：769 1974 .

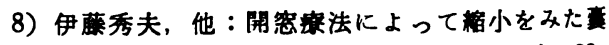
胞性疾患の症例について（抄）。科誌 23: 2421974.

9）西嶋克巳，他：小児額部䓂胞性疾患について武 みた開空捬. 小歯誌 4: 84 1966.

10) Thoma, K.H.: Oral Surgery. ed 4, Mosby Co,St Louis, 1963, p 855.

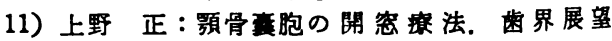


34: 8491969.

12) Seldin, S.D.: Amelblastoma in Young Patients: report of two cases. J Oral Surg 19: 508 1961.

13）池尻茂，他：闰密後 4 年を释過したェナメル 上皮后の1例（抄）. 日口外誌 20：1941974.

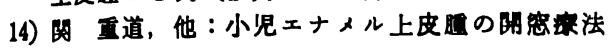

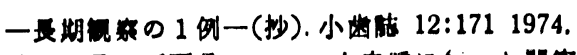

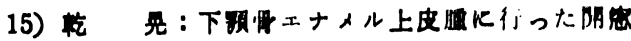
法法。日本科保誡 334: 191970 .

16) Sanuel, H. S.: Marsupialization: Effective management of large maxillary cyst. Oral Surg 20: 6751965. 